Artigo / Article

\title{
Post-transfusion red cell alloimmunisation in patients with acute disorders and medical emergencies
}

\author{
Aloimunização após transfusão de concentrado de hemácias em pacientes atendidos em \\ um serviço de emergência
}

Francisco W. R. Santos ${ }^{1}$

Silvia Maria M. Magalhães ${ }^{2}$

Rosa Maria S. Mota

Maria Helena Pitombeira ${ }^{4}$

\begin{abstract}
Alloimmunisation following red cell transfusion is a complication in patients with chronic diseases requiring multiple transfusions. The aim of this study was to determine the frequency of alloimmunisation, to identify involved alloantibodies, to establish risk factors and to quantify the alloimmunisation risk in patients with acute disorders who received red cell transfusion at the Instituto Dr. José Frota from January 1999 to January 2001. Of the 5,690 recipients who received 16,547 units of red blood cells, 4,025 were men and 1,665 were women. Recipients with previous alloimmunisation or with time of hospital stay less than one week were excluded $(n=501)$. Red cell alloantibodies were detected in 120 recipients (2.1\%): 60 men (1.49\%) and 60 women (3.60\%). Alloimmunisation was 2.4 fold more frequent in women and $93.33 \%$ of the women were pregnant prevously. The average number of units transfused in the alloimmunised recipients was 4.68: 4.97 units in men and 4.40 units in women. In nonalloimmunised recipients the average was 2.87 units and the risk of alloimmunisation was $0.83 \%$ : $0.59 \%$ in men and $1.44 \%$ in women. The most frequent allo-antibodies were: anti-E (18.25\%) and anti-D (16.06\%) from a total of 137 allo-antibodies detected. The median time for detection of allo-antibodies was 20.88 days. The risk of alloimmunisation detected was high considering the average number of units transfused. The age of recipients and the longer life expectancy increase the probability of further transfusion requirements in this group. Our findings point out the necessity of modifications in the current medical transfusion support indication, including in patients with acute disorders in order to prevent alloimmunisation. Rev. bras. hematol. hemoter. 2007;29(4):369-372.
\end{abstract}

Key words: Allo-antibodies; alloimmunisation; red cell; transfusion.

\section{Introduction}

Blood transfusions commonly result in the production of alloantibodies against one or more red cell (RBC) antigens, which complicates subsequent transfusions. The probability of alloimmunisation depends on the number and frequency of transfusions, antigen immunogenicity and the recipient's immune response. The influence of ethnic and antigenic pattern differences between donors and recipients has also been reported. ${ }^{1}$ According to different reports, the overall immunisation risk, defined as the total number of alloantibodies detected divided by the total number of transfused units, varies from 0.4 to $1.0 \% .^{2,3}$ Several studies have demonstrated different frequencies of alloimmunisation after multiple blood transfusions in patients with chronic diseases. ${ }^{1,4-10}$ To the best of our knowledge, a large scale

${ }^{1}$ Federal University of Ceará and Instituto Dr. José Frota - Brazil.

${ }^{2}$ Department of Clinical Medicine, Federal University of Ceará/Hemoce, Brazil.

${ }^{3}$ Department of Mathematics and Statistics, Federal University of Ceará, Brazil.

${ }^{4}$ Department of Clinical Medicine, Federal University of Ceará, Brazil.

Correspondence: Francisco Wandemberg Rodrigues dos Santos

Rua Carolina Sucupira 100/902

60140-120 - Fortaleza-CE - Brazil

Tel.: 5585 3246-0484 / 3255-5205 / 8806-5103

E-mail:wandemberg@oi.com.br 
study on screening patients with acute diseases or medical emergencies for alloantibodies has not been performed.

The identification of alloantibodies in the recipient's serum makes further transfusions safer as compatible blood can be provided. Especially for patients prone to receive multiple transfusions, compatibility for red cell antigens must include ABO, Rh as well as minor antigens, although the majority of haemolytic transfusion reactions are due to a limited number of alloantibodies. ${ }^{11}$ Antibodies against highfrequency antigens can hinder obtaining suitable blood units and a lack of phenotypic compatibility between donor and recipient blood may result in potential life-threatening complications.

We performed a study to determine the frequency of red cell alloimmunisation following transfusion in patients admitted to the Instituto Dr. José Frota with acute disorders and medical emergencies. The identification of alloantibodies, risk factors and alloimmunisation risk were also studied.

\section{Patients and Methods}

Pre-transfusion and sequential post-transfusion samples were obtained from patients admitted to the Instituto Dr. José Frota to treat acute disorders and medical emergencies between January 1999 and January 2001. Only patients who required blood transfusion during the course of their illness were included. Patients with alloantibodies detected before the first transfusion or with hospital stays of less than one week were not eligible for analysis. This study was submitted to the local Ethics Committee.

Prior to every transfusion, the selected patients' serum was screened for the presence of antibodies using the gel centrifugation test (ID-card/Liss-Coombs, DiaMed, Switzerland). ${ }^{12}$

A selected two-cell set of reagent RBCs for antigen detection (ID-Diacell I-II- DiaMed, Switzerland) was used according to the manufacturer's instructions. An auto-control was systematically employed. The posttransfusion samples were obtained weekly until the time of discharge of the patient. If screening was positive, the antibody specificity was determined with commercial panels of 11 cells (ID-DiaPanel DiaMed, Switzerland) tested by similar methods. Tests with enzyme-treated cells (bromelin) were also carried out in all patients with a positive test. The tests were performed at room temperature, $4^{\circ} \mathrm{C}$ and $37^{\circ} \mathrm{C}$. Non-matched phenotypic blood was transfused unless an antibody had been detected. In this case, only units matched for the specific antibody were transfused.

Statistical analysis employed the logistic regression and the chi-square test or Fisher's exact test. Groups were assumed to differ significantly when the probability level was less than 0.05 .

\section{Results}

From the total of 6,191 patients who received red cell transfusion in the period previously outlined, 5,690 were enrolled. The patients' ages ranged from 1 to 88 years. There were 4,025 men (70.74\%) and 1,665 women (29.26\%). The total number of transfused units was 16,547. Men received an average of 2.97 units (range: 1 to 22) and women an average of 2.75 units (range: 1 to 21). Mean time of follow-up was 30 days (range: 7 to 240), and mean frequency of testing was 4 days (range: 2 to 37). Red cell alloantibodies were detected in 120 recipients (2.1\%), 60 men and 60 women. The rate of alloimmunisation was $1.49 \%$ in men and $3.6 \%$ in women $(p<$ 0.0001). Fifty-six women (93.33\%) were known to have been pregnant previously. The patients' mean age was 35.7 years for men and 46.13 years for women ( $p=0.003$ ). The distribution of alloimmunised and non-alloimmunised according to $\mathrm{ABO}$ system and the Rh-D antigen did not differ significantly. In the alloimmunised group the average number of units transfused was 4.97 units for men and 4.44 units for women. No difference was observed between men and women ( $p=$ $0.46)$. In the non-alloimmunised group this average number was 2.94 units for men and 2.69 units for women. The difference was significant between men $(p=0.001)$ and women $(p=0.002)$ (Table 1$)$.

A total of 137 antibodies were detected in the 120 patients. Among 130 identified antibodies (94.89\%), the most frequent were anti-E (19.23\%), anti-D (16.92\%), anti-M (12.31\%) and anti-Kell (9.23\%). Time taken to detect alloantibodies ranged from 3 to 97 days (mean 20.88 days). The risk of alloimmunisation, defined as the total number of alloantibodies detected (137) divided by the total number of transfused units $(16,547)$, was $0.83 \%$ for the entire group, $0.59 \%$ for men and $1.44 \%$ for women. In 13 immunised patients (10.83\%) more than one antibody were detected. A total of 30 alloantibodies were detected in 7 men and 6

Table 1 . Distribution of alloimmunised and non-alloimmunised patients according to sex, age, rate of alloimmunisation, risk of alloimmunisation and number of units transfused

\begin{tabular}{ccccc}
\hline & Sex & Alloimmunised & Non-Alloimmunised & $P$ \\
\hline Number & $\mathrm{M}$ & 60 & $3,965(71.18 \%)$ & \\
Mean & $\mathrm{W}$ & 60 & $1,605(28.82 \%)$ & \\
Age (years) & $\mathrm{M}$ & 35.7 & 30.30 & \\
& $\mathrm{~W}$ & 46.13 & 40.94 & \\
Mean number of & $\mathrm{M}$ & 4.97 & 2.94 & 0.001 \\
units transfused & $\mathrm{W}$ & 4.44 & 2.69 & 0.002 \\
Rate of & $\mathrm{p}$ & 0.46 & $<0.001$ & \\
allolmmunisation & $\mathrm{M}$ & $1.49 \%$ & - & \\
& $\mathrm{W}$ & $3.60 \%$ & - & \\
Risk of allo & $\mathrm{p}$ & $<0.01$ & & \\
Immunisation \% & $\mathrm{M}$ & $0.59 \%$ & - & \\
\hline
\end{tabular}

M: man; F: woman 
women. The average number of units transfused in this group was 4.43 for men and 5.67 for women. These results indicate that once the patient is immunised, the risk of acquiring more than one antibody increases.

\section{Discussion}

The risk of alloimmunisation depends on the recipient's exposure to foreign antigens, their immunogenicity, number of units transfused and underlying disease ${ }^{8}$ Blood transfusion in patients with acute disorders and medical emergencies frequently makes phenotyping before transfusion unfeasible. Moreover, most patients will probably only undergo only this transfusion episode during their lifetime and therefore it is unlikely that they become transfusion-dependent. Although antibody levels decline and become undetectable over time, re-exposure can cause delayed reactions after incompatible blood transfusions.

Several studies have examined the frequency and rate of alloimmunisation in patients with different chronic diseases. ${ }^{1,4-10}$ However, very few data have been reported concerning alloantibody development in acute disorders. The frequency of alloimmunisation in patients with sickle cell anaemia has been reported to range from 2.6 to $76 \% .^{13}$ In patients with thalassemia who receive multiple transfusions, the frequency was reported to be $22 \%{ }^{14}$ Redman et al., screened patients who underwent elective surgery and reported RBC alloantibodies in $8.4 \%$ of patients. ${ }^{15}$

The frequency of post-transfusion antibodies in our patients was $2.1 \%$. This figure is higher than the frequency of $0.25 \%$ reported when random blood units were transfused ${ }^{4}$ and lower than the frequency of $8 \%$ reported in general surgical patients after transfusion of an average of three units of red cells. ${ }^{15}$ However, our frequency of alloimmunisation may be underestimated considering that the time of follow-up was limited to hospital stay and some transfused patients were tested only once before discharge.

The risk of alloimmunisation is known to be influenced by recipient gender. In our study, in spite of very similar averages of units transfused in men and women (2.97 and 2.75 respectively) the rate of alloimmunisation was significantly higher in women.

The risk of alloimmunisation per transfused unit is reported to range from 0.5 to $5.9 \% .^{2}$ The overall alloimmunisation risk we demonstrated $(0.83 \%)$ is in accordance with these figures.

The average number of units transfused in patients receiving multiple transfusions who develop alloantibodies ranges from 16 to 25 units. ${ }^{2,6,8}$ In our patients an average of 4.68 units was transfused in the alloimmunised group. Factors such as underlying disease, the transfusion policy, matching red cells only for $\mathrm{ABO}$ and Rh-D antigens, the sensitivity of tests using a two-cell set of reagent red cells, lack of leucodepleted RBC 10 for patients with acute disorders, and deficient availability of negative Rh-D blood units play an important role in the difference of results obtained.

Alloimmunised recipients are more likely to develop additional antibodies. In our series, thirteen patients developed more than one antibody. The risk of additional antibody formation therefore increased 3.1 fold. This figure agrees with several authors who found an increased risk between 2.7 and 3.3 fold. ${ }^{2,6}$

For 7 of 137 antibodies (5.1\%) the specificity could not be identified. This figure is lower than the $22.5 \%$ related by Schonewille et al. ${ }^{2}$ and the $17.6 \%$ reported by Redman et al. ${ }^{15}$ This difference might be explained by the underlying diseases. Patients with acute disorders have no red cell auto-antibodies or associated morbid conditions.

This study represents the first prospective analysis of red cell alloantibody in a large series of patients with acute disorders and medical emergencies carried out in Brazil. Because of intensified treatment and consequent improvement in survival and longer life expectancy of the population it is important to focus on the incidence and risk of alloimmunisation in this group of patients, especially in women of childbearing age.

\section{Resumo}

A aloimunização eritrocitária após transfusão de concentrado de hemácias é uma complicação em pacientes com doenças crônicas que necessitam de transfusões de repetição. Esse estudo objetivou determinar a freqüência de aloimunização, identificar os aloanticorpos, estabelecer os fatores de risco envolvidos e quantificar o risco de aloimunização em pacientes com condições clínicas agudas, submetidos à transfusão de concentrados de hemácias no Instituto Doutor José Frota, utilizando a técnica de gel centrifugação. Foram analisados 5.690 receptores transfundidos com 16.547 concentrados de hemácias, sendo 4.025 do sexo masculino e 1.665 do sexo feminino. Foram excluídos 501 receptores com aloimunização prévia ou tempo de permanência hospitalar inferior a uma semana. Em 120 receptores (2,1\%) foram detectados aloanticorpos eritrocitários, sendo 60 do sexo masculino $(1,49 \%)$ e 60 do sexo feminino (3,60\%). A aloimunização foi 2,4 vezes mais freqüente no sexo feminino, sendo que 93,33\% das mulheres tinham história de gestação prévia. A média transfusional nos receptores aloimunizados foi de 4,68 bolsas, sendo 4,97 bolsas nos homens e 4,40 bolsas nas as mulheres. Nos pacientes não aloimunizados a média transfusional foi de 2,87 bolsas. $O$ risco de aloimunização foi de 0,83\%, sendo 0,59 no sexo masculino e $1,44 \%$ no sexo feminino. Os aloanticorpos detectados com maior freqüencia foram anti-E $(18,25 \%)$ e anti-D $(16,06 \%)$ de um total de 137 aloanticorpos. O tempo médio de detecção dos aloanticorpos foi de 20,88 dias. O risco de aloimunização observado foi elevado para a média transfusional de receptores. A média de idade dos pacientes e o aumento da expectativa de vida aumentam a possibilidade de que transfusões posteriores sejam necessárias, sinalizando a necessidade de modificar o atual suporte hemoterápico a esses pacientes. Rev. bras. hematol. hemoter. 2007;29(4):369-372. 
Palavras-chave: Aloanticorpos; aloimunização; eritrócitos; transfusão.

\section{References}

1. Vichinsky EP, Earles A, Johnson RA, Hoag MS, Williams A, Lubin B. Alloimmunization in sickle cell anemia and transfusion of racially unmatched blood. N Engl J Med. 1990;322:1617-21.

2. Schonewille H, Haak HL, van Zijl AM. Alloimmunization after blood transfusion in patients with hematologic and oncologic diseases. Transfusion. 1999;39:763-71.

3. Walker RH, Lin DT, Hartrick MB. Alloimmunization following blood transfusion. Arch Pathol Lab Med. 1989;113:254-61.

4. Cummins D, Contreras M, Amin S, Halil O, Downhan B, Yacoub MH. Red cell alloantibody development associated with heart and lung transplantation. Transplantation. 1995;59:1432-5.

5. Davies SC, McWilliam AC, Hewitt PE, Devenish A, Brozovic M. Red cell alloimunization in sickle cell disease. Br. J. Haematol. 1986;63:241-5.

6. Fluit CRMG, Kunst VAJM, Drenthe-Schonk AM. Incidence of red cell antibodies after multiple blood transfusions. Transfusion 1990; 30:532-5.

7. Michail-Merianou V, Pamphili-Panousopoulou L, Piperi-Lowes L, Pelegrins E, Karaklis A. Alloimmmunization to red cell antigens in thalassemia: comparative study of usual better-match transfusion programmes. Vox Sang. 1987;52:95-8.

8. Ramsey G, Cornell FW, Hahn LF, Larson P, Issitt LB, Starzl TE. Red cell antibody problems in 1000 liver transplants. Transfusion 1989;29:396-400.

9. Ramsey G, Smietana SJ. Multiple or uncommon red cell alloantibodies in women: association with autoimmune disease. Transfusion 1995;35:582-6.

10. Singer ST, Wu V, Mignacca R, Kuypers FA, Morel P, Vichinsky EP. Alloimmunization and erythrocyte autoimmunization in transfusion-dependent. Thalassemia patients of predominantly Asian descent. Blood 2000;96:3368-73.

11. Chow MP, Hu HY, Lyou JY, Lin JS, Yung CH, Lee A et al. Red cells, HLA and platelet antibody formation in patients with multiple transfusions. Acta Haematol. 1994;92:57-60.

12. Bromilow IM, Eggington JA, Owen GA, Duguid JKM. Red cell antibody screening and identification: a comparison of two column technology methods. Br J Biomed Sci 1993; 50: 329-333.

13. Olujohungbe A, Hambleton I, Stephens L, Serjeant B, Serjeant G. Red cell antibodies in patients with homozygous sickle cell disease: a comparison of patients in Jamaica and the United Kingdom. Br. J. Haematol. 2001;113:661-5.

14. Spanos TH, Karageorga M, Ladis V, Hatziliami A, Kattamis CH. Red cell alloantibodies in patients with thalassemia. Vox Sang. 1990;58:50-5.

15. Redman M, Regan F, Contreras M. A prospective study of the incidence of red cell alloimmunisation following transfusion. Vox Sang 1996;71:216-20.

Avaliação: Editor e dois revisores externos

Conflito de interesse: não declarado

Recebido: 16/08/2006

Aceito após modificações: 31/03/2007 